\title{
FILOSOFIJOS PASKIRTIES SAMPRATA JUOZAPO GOLUCHOVSKIO TRAKTATUOSE
}

\author{
The Concept of the Purpose of Philosophy \\ in the Tractates of Józef Gołuchowski
}

\begin{abstract}
SUMMARY
The article is a continuation of the analysis of the ideas of Józef Gołuchowski, a philosopher of Polish origin, who briefly taught at Vilnius University in the early 19th century. This article examines the statements on the purpose of philosophy in his tractates: "An outlook on Mathematics through its influence on human education", "On the role of the Philosophy in the life of entire nations and individual persons" and the tractate which was submitted in 1821 to contest the seat of professor of philosophy at Vilnius University. We compare the ideas of Friedrich Schelling and our author, discuss Goluchowski's beliefs about the relationship of philosophy with religion and science, reconstruct the arguments why philosophy, which does not provide direct benefits, is significant and even necessary for society.
\end{abstract}

\section{SANTRAUKA}

Tęsdami Juozapo Goluchovskio, lenkų kilmės filosofo, kuris XIX a. pradžioje trumpai dėstė Vilniaus universitete, idèjų analizę, šiame straipsnyje nagrinëjame jo filosofijos paskirties sampratą, susiklostančią jo traktatuose "Požiūris į matematikos įtaką žmogaus išsilavinimui", „Filosofijos reikšmė ištisų tautu ir atskiru individu gyvenime" ir veikale, pateiktame Vilniaus universiteto paskelbtam konkursui filosofijos profesoriaus etatui užimti. Palyginame Friedricho Schellingo ir mūsu autoriaus idẻjas, aptariame Goluchovskio įsitikinimus apie filosofijos santykius su religija ir mokslu, rekonstruojame argumentus, kodèl tiesioginės naudos neduodanti filosofija yra reikšminga ir net būtina visuomenei.

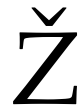

urnalo „Logos“ skaitytojai su Juozapo Goluchovskio mintimis galëjo susipažinti iš pastarajij dešimtmeti publi- kuotų straipsnių apie jo moralès ir mąstymo reikšmès sampratas (Vabalaitė 2012: 6-14; 2017: 82-86). Tęsdami šio fi- 
losofo idejjų tyrinèjimus, pradedame straipsniu cikla, kuriame analizuosime romantizmo bruožus ankstyvuosiuose Goluchovskio traktatuose. Tyrinètojams žinomi trys traktatai, kuriuos autorius parašè prieš tapdamas Vilniaus universiteto dèstytoju. Tai jau nagrinètas darbas apie matematikos ittaką žmogaus išsilavinimui ir taip pat jau nagrinètas rankraštis, pateiktas Vilniaus universiteto paskelbtam konkursui filosofijos profesoriaus etatui užimti, bei labiausiai jaunąji autorių išgarsinęs veikalas „Filosofijos reikšmė ištisu tautu ir atskiru individu gyvenime“. Anot Lietuvos filosofijos istorijos žinovo Daliaus Viliūno, būtent ši Goluchovskio knyga „,buvusios Abiejų Tautu Respublikos erdvëje <...> sukèlè tikrą entuziazmą" (Viliūnas 2014: 224); „,buvo daugiau kaip ištisą šimtmeti trukusios lenku "tautinès filosofijos" (Filozofia Narodowa) kūrybos svarbiausioji ištaka, jos „idejjinis manifestas“ (ten pat). Kaip žinome, prasidejus Goluchovskio atleidimo iš užimamu pareigu procesui, ši kūrini skaite ir jo ištraukas vertė tų laikų Vilniaus universiteto kuratorius Nikolajus Novosilcevas (Jachimowski 1933: 56-65), tad galime teigti, jog traktatas buvo svarbus ne vien lenku skaitytojams. Ji vertinti kaip reikšmingą Lietuvos filosofijos istorijos paminklą mums leidžia ir tai, kad jos klasikas Romanas Plečkaitis išverte šio Goluchovskio traktato ištraukas ir jas publikavo chrestomatiniame leidinyje Filosofija Vilniaus universitete 1579-1832. Kita vertus, siekiame parodyti, kad šis ir kiti mūsu autoriaus traktatai turi ne vien istorinę reikšmę, o aktualiausiai mūsų dienomis skamba tos mintys, kurias Goluchovskis rašè apie universalaus išsilavinimo ir fundamentalesnio tikrovès suvokimo reikšmę. Tad straipsnių ciklą pradedame nagrinėdami teiginius, kuriais jis aiškina filosofijos, kaip visos dvasinès sferos pagrindo, reikalingumą visuomenei.

Garsiausio traktato pradžioje mūsų autorius deklaruoja, kad „filosofija yra pats gyvenimas, iš tikruju ji būtu gyvenimo žydejjimas" (Gołuchowski 1822: 5). Platesnis kontekstas leidžia gyvenimo metaforą suprasti kaip reiškiančią be paliovos kintančią ir mentalinę, ir fizinę plotmes apimančią tikrovę, o pačią filosofiją - kaip netarpišką jos intelektualinę izžvalgą. Būtent filosofinè žiūra atverianti iš pradžių vieninga, vèliau išsišakojanti visu dalyku ir juos analizuojančiu mokslu pamatą. Akivaizdu, kad tokią prielaidą Goluchovskis perima iš Friedricho Schellingo, kuriam, beje, ir dedikuoja ši savo kūrinį. Nors logiška būtų ieškoti jų abiejų mąstymo panašumų, Goluchovskio traktatas visiškai skiriasi nuo tuo laiku jau publikuotu Schellingo veikalų, taip pat net ir temiškai jam artimiausiu "Paskaitu apie akademiniu studiju metodą". Net ir šiose, ne vien filosofams skirtose paskaitose Schellingas pateikia nuoseklu filosofini visu mokslu pagrindų aiškinima, teigia, kad filosofija yra aukščiausias mokslas, idealiai atskleidžiantis pamatini žinojimą (Urwissen), ir argumentuotai aprašo jos vietą būties ir jos pažinimo struktūroje (Schelling 1803: sk. 1, 5). Goluchovskis laikosi priešingos pozicijos ir tvirtina, jog apie filosofiją stengiasi rašyti suprantamai neprofesionalams, nesiekti nuoseklios argumentacijos, ne įrodinèti, o retorinèmis priemonèmis įtikinti skaitytojus. Autorius teigia, kad konkrečiu filosofijos sistemu plètojimas ir jų tarpusavio pole- 
mika yra greičiau kenksmingi, negu naudingi, nes kai ivvairių krypčių filosofai pateikia kitų krypčių filosofų teorijų kritika, nespecialistai ją dažniausiai supranta kaip visos filosofijos apskritai klaidingumo, tad ir nereikalingumo, pripažinimą. Pripažindami, kad šioje iž̌valgoje yra dalis liūdnos tiesos, negalime kartu su mūsų romantiku atmesti argumentuotos filosofinès polemikos reikšmès, nes tik joje išaiškejja, kiek patikimi yra kad ir vaizdingiausi būties problemu aprašymai.

Taigi atsakydami i klausima, kokios mintys glūdi už romantizmo literatūrai būdingu grožybių, turime remtis aptariamo traktato lyginimu su akademiškesniu pobūdžiu pasižyminčiais Goluchovskio darbais. Nors tiesiogiai apie filosofijos paskirti traktate „Požiūris ì matematikos ittaką žmogaus išsilavinimui“ nėra svarstoma, čia kelis kartus nurodoma, kad matematika, kaip ir filosofija, leidžia mąstyti apie gilesni, negu tiesiogiai jusliškai atsiveriantis, tikrovès kloda, suvokti ją kaip ivvairiais santykiais susijusią visumą. Autorius nurodo, kad matematika kartu su filosofija žmogui atskleidžia transcendentalinę srití, matematiniam mąstymui priskiria galias pajusti „vienovę su visa gamta“, „dangaus sferu harmoniją“, išgirsti „,tolimų kraštų himnus" (Gołuchowski 1825: 32), nors iprastai šios galios pripažistamos būdingomis filosofijai. Žinoma, galima rekonstruoti ir autoriaus požiūrị i šių mokslų skirtumus. Jo nuomone, matematika skatina tuo pat metu sutelkti dèmesị i daugybę aspektų, ižvelgti ir dalyko visuma, ir atskiras dalis, sukurti nuoseklią žinių grandinę bei nepažeisti detaliu samprotavimo taisyklių. Apibendrindami vèlesnių traktatų mintis, galime teigti, jog filosofijos ypatybè esanti ta, kad ji pradeda nuo bendriausių dalykų ižvalgos ir tik remdamasi organiškos vienovès žiūra aiškinasi joje susitelkiančias įvairybes.

Šiuose traktatuose tik išorinę juslinę patirti analizuojanti ir apibendrinanti filosofija vertinama kritiškai. Konkursui pateiktame traktate Goluchovskis pabrèžia, kad tikrojoje filosofijoje kalbama ne apie išorinių formų bei jų santykių suvokimą, ir teigia, kad tokia refleksija gali būti tik „lygties, kurioje nežinoma apibrèžta visais kitais žinomais dydžiais, išsprendimas; tai tèra vieno vertimas i kitą; tai - paprastesnis arba painesnis skaičiavimas, bet ne daugiau kaip skaičiavimas, kuriame, išskyrus santykinius vaizdinius, nieko nesugebame suvokti“ (Goluchovskis 2008: 306). Traktate apie filosofijos reikšmę analogiška mintis formuluojama nuosaikiau, autorius klausia, ar nèra taip, kad amžinybès žiūra besiremianti filosofija, kuri „skatina pati gyvenima, ir tuo pačiu ji nukreipia i̇ amžinosios šviesos spindulius" (Gołuchowski 1822: 122) yra išmintingesnè už tą kuri „tik nustato šių spindulių judejjimo formules, bet ju pačių negali įdegti“" (ten pat). Filosofijos reikšmė esanti atskleisti nesantykiškus dalykus, išvaduoti žmogaus intelektą nuo dvejonių, kuris iš kelių požiūrių yra arčiau tiesos.

Tokiu būdu Goluchovskio, kaip ir daugelio kitų filosofų, aiškinimuose filosofija atsiduria tarp religijos ir kitu mokslų. Originalesnè yra jo nuomonè, kodèl mokslams negali padèti religija ir kaip šiomis aplinkybėmis jiems padeda filosofija. Filosofas teigia, kad iš esmès religija yra dvasios nusiraminimas Dievuje, o filosofija - dieviškumo ieškojimas 
visame, kas egzistuoja, „dvasios judèjimas per visas erdves bei visus laikus siekiant izžvelgti Dievo šlovę" (ten pat: 54). Konkretūs mokslai, kaip to judejjimo keliai, kelia reikalavimą apmąstyti ne vien tikrovės centra, bet ir daugybę ivvairių jos sričių ir rezultatus išreikšti sąvokomis. Tose periferinėse srityse intelektas susiduria su nevienaprasmiais vaizdiniais, tad jam kyla grèsmè pasimesti abejonėse. Filosofija, anot autoriaus, šiuo atveju mokslams yra vedlys, raginantis specializuotuose keliuose nepamesti iš akių jų pačių pamatinių principų. Be to, ji leidžia vienas nuo kito atsiskyrusių mokslų tyrinėtojams apmąstyti visų tikrovės pažinimo sričių sąsają.

Žinoma, pamatinių principų supratimas yra dar svarbesnis gilinantis i filosofines teorijas. Goluchovskis išreiškia radikalią nuomonę, kad filosofiškai mąstoma tik kuriant savo filosofiją. Kita vertus, jis pripažista, kad „gilios filosofijos supratimui iš pagrindų reikia beveik tiek pat genialumo, kiek ir tam, kad ją pats sukurtum" (ten pat: 157). Taigi norint suvokti kito filosofo mintis, būtina savarankiškai pasekti jo keliu nuo pirminès izžvalgos iki išplètotos teorijos ir nepamiršti, jog sąvokos filosofijoje yra tik eskizai, nurodantys tai, kas kitam kalbos priemonèmis adekvačiai negali būti perduota.

Pats filosofas pripažista, kad vien utilitariniuose rūpesčiuose paskendusiems biurgeriams ir tik praktinès savo mokslo taikymo naudos siekiantiems mokslininkams rimta filosofija atrodo sudètinga, bet nieko verta. Manytume, kad tik antraštę ar trumpą žinutę lengvai suvokiantiems mūsų dienų žmonèms ji atrodytų taip pat, kaip nurodè mūsų autorius, arba net dar prasčiau. Aktualumo nepra- rado ir daug kitų Goluchovskio minčių apie neadekvačiai suprantamą filosofijos paskirti, filosofams keliamus priekaištus dèl jų veiklos nenaudingumo ir sieki juos motyvuoti imtis tuo momentu "topinių" temų. I kelias iš jų, šiuolaikiškai kalbančias apie realų publikos ir vyriausybès santyki su filosofija, norètume atkreipti skaitytojų dèmesị:

Reikia atsižvelgti ne tik i didžiosios minios poreikius, nes kilniausi tautos poreikiai, kaip ir kilniausios jos mintys išsakomos tik saujelès tų, kurie jokiu būdu nesitenkindami tuo, kas kitus visiškai užpildo, savyje jaučia veržimąsi taip pat ikopti i aukščiausią viršūnę. Valstybe turi jais pirmiausia rūpintis ir jų lavinimui steigti įstaigas, jei iš ju ir neturètu jokios tiesioginès naudos, netgi dèl jų turètų patirti auku. <...> kaip jie [Platonai] gali atsirasti, jei mokslininkai visose mokslinèse prekyvietėse aukščiausią filosofijos pakilimą apšaukia nenaudingu, perspèja dèl jos jaunimą kaip dèl kenksmingu arba bent laiką gaišinančių svajonių, <...> jei ją ivelka tik $\mathfrak{i}$ tokias formas, kurias laiko naudingomis arba savo mokslams, arba kokiems nors kitiems verslams? (Goluchovskis 1979: 120-1).

Neįmanoma apskaičiuoti, kokių baisių nuniokojimu sukelia paviršutiniška filosofija ir kaip stipriai ji stabdo ir gyvenimo, ir mokslo polèkį. O ji bus paviršutiniška nes vis dèlto kažkokia filosofija visuomet turi būti, kol valstybè viešai jos nekultivuos ir šiam kultivavimui neskatins geriausių protų; toliau, kol ji, leidusi jos viešai mokytis, jos nepaliks jos pačios vystymuisi, bet ją tampys šen ir ten pagal savavališkai sugalvotus tikslus (ten pat: 123).

Citatose tiesiai teigiama, kad filosofija nèra naudinga tiesiogine šio žodžio prasme, o siekiant jos praktinio naudingumo, kyla grèsmė nukrypti i paviršu- 
tiniškus paauklëjimus ar pasvarstymus. Visiškai pritardami autoriui turime paklausti, kodèl, jo nuomone, filosofija vis dèlto turètų būti būtina visuomenès gyvenimo dalis. Rekonstravę Goluchovskio traktatu mintis, galime išskirti dvi tarpusavyje susijusias jos būtinumo priežastis. Pirmoji yra ta, kad visuomenės gerovè reiškia ne vien jos nariu gerovę, bet ir joje egzistuojančiu tarp jų ir ma- terialinės naudos neteikiančių, veiklos sričiu i̇vairovę. Tad pats pažinimas, taip pat ir filosofijos pažinimas, gali būti ne vien priemonè, o tikslas savaime. Antroji yra ta, kad filosofija išplečia akiratí, leidžia savo veiklos sriti pamatyti plačiame kontekste. Tuomet individas mato ne vien savo, bet ir bendrus interesus ir, mūsu autoriaus nuomone, per filosofiją ima dalyvauti bendrajame gyvenime.

\section{IŠVADOS}

Tikrają filosofiją mūsų aptariamas autorius interpretuoja kaip gyvenimišku tikslų nesiekiančią amžinų pradų ižvalgą ir jų sklaidos apmąstymą. Esmès įžvalgos aspektu ir pagarba tam, kas dar negali būti paaiškinta sąvokomis, filosofija esanti panaši i religiją. Viena jos paskirčiu yra būti savotišku tarpininku tarp religijoje suponuojamu slèpinių, hipotezių apie bendrus tikrovès pagrindus ir nuosekliais samprotavimais formuluoja-

\section{Literatūra}

Goluchovskis Juozapas Vaitiekus. 2008. Konkursinis traktatas, Viliūnas D. (sud.). Apšvietos ir romantizmo kryžkelèse. Filosofijos kryptys ir kontroversijos Lietuvoje XVIII a. pabaigoje-pirmojoje XIX a. pusëje: 262-230. Iš lenkų k. vertė D. Viliūnas. Vilnius: KFMI.

Goluchovskis Juozapas. 1979. Filosofijos reikšmė ištisų tautų ir atskirų individų gyvenime. I d. III sk., Plečkaitis R. (sud.) Filosofija Vilniaus universitete 1579-1832: 109-127. Iš vokiečių $\mathrm{k}$. vertė R. Plečkaitis. Vilnius: Mintis.

Gołuchowski Joseph. 1822. Die Philosophie in ihrem Verhältnisse zum Leben ganzer Völker und einzelner Menschen. Erlangen: J. J. Palm und Ernst Enke.

Gołuchowski Józef. 1825. O wpływie matematyki na wykształcenie człowieka. Przeł. M. Mochnacki, Dziennik Warszawski: II (5): 3-36.

Jachimowski Tadeusz. 1933. Dokumenty do spra- mų mokslų teorijų. Filosofijos teikiamas platus ir gilus tikrovès suvokimas esąs vertingas pats savaime, bent jau ne mažiau kaip bet kuri kita dvasinè veikla. Be to, toks suvokimas padedąs izžvelgti bendraji interesą ir pasiryžti jo siekti. Žinoma, lieka neaišku, kaip i̇manoma pati netarpiška tikrovès įžvalga, kas yra tas amžinasis pradas, tad šiuos ir kitus Goluchovskio filosofijos klausimus nagrinėsime kituose straipsniuose.

wy pozbawienia katedry filozofji Józefa Gołuchowskiego w Uniwersytecie Wileńskim, Archiwum komisji do badania historji filozofji w Polsce 5: 1-72. Krakow: Nakładem Polskiej Akademji umiejętności.

Schelling Friedrich Wilhelm Joseph. 1803. Vorlesungen über die Methode des akademischen Studiums. Pasiekiamas: https://www.projekt-gutenberg. org/schellin/methstud.html [žr. 202002 21]

Vabalaitè Rūta Marija. 2012. Moralès filosofijos ypatybès Juozapo Goluchovskio „Konkursiniame traktate“, Logos-Vilnius 73: 6-14.

Vabalaitè Rūta Marija. 2017. Mąstymo reikšmès interpretacija pirmajame Juozapo Goluchovskio traktate, Logos-Vilnius 90: 82-86.

Viliūnas Dalius. 2014. Filosofija Vilniuje XIX amžiaus pirmoje pusejje. Vilnius: Lietuvos kultūros tyrimų instituto leidykla. 